\title{
Nuclear Medicine Technology Progress Report for Quarter Ending September 30, 1978
}

$$
\text { F. F. Knapp, Jr. }
$$

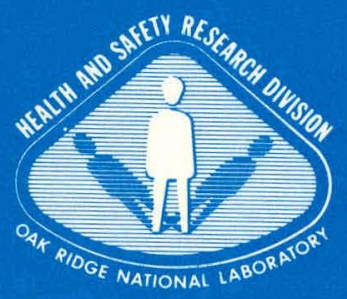

OAK RIDGE NATIONAL LABORATORY OPERATED BY UNION CARBIDE CORPORATION - FOR THE DEPARTMENT OF ENERGY 


\section{DISCLAIMER}

This report was prepared as an account of work sponsored by an agency of the United States Government. Neither the United States Government nor any agency Thereof, nor any of their employees, makes any warranty, express or implied, or assumes any legal liability or responsibility for the accuracy, completeness, or usefulness of any information, apparatus, product, or process disclosed, or represents that its use would not infringe privately owned rights. Reference herein to any specific commercial product, process, or service by trade name, trademark, manufacturer, or otherwise does not necessarily constitute or imply its endorsement, recommendation, or favoring by the United States Government or any agency thereof. The views and opinions of authors expressed herein do not necessarily state or reflect those of the United States Government or any agency thereof. 


\section{DISCLAIMER}

Portions of this document may be illegible in electronic image products. Images are produced from the best available original document. 
Printed in the United States of America. Available from National Technical Information Service

U.S. Department of Commerce

5285 Port Royal Road, Springfield, Virginia 22161

Price: Printed Copy $\$ 4.50$; Microfiche $\$ 3.00$

This report was prepared as an account of work sponsored by an agency of the United States Government. Neither the United States Government nor any agency thereof, nor any of their employees, contractors, subcontractors, or their employees, makes any warranty, express or implied, nor assumes any legal liability or responsibility for any third party's use or the results of such use of any information, apparatus, product or process disclosed in this report, nor represents that its use by such third party would not infringe privately owned rights. 
ORNL/TM-6639

Contract No. W-7405-eng-26

HEALTH AND SAFETY RESEARCH DIVISION

NUCLEAR MEDICINE TECHNOLOGY PROGRESS REPORT

FOR QUARTER ENDING SEPTEMBER 30, 1978

F. F. Knapp, Jr.

Work sponsored by

DOE Office of Health and

Environmental Research

Date Published: February, 1979

NOTICE This document contains information of a preliminary nature. It is subject to revision or correction and therefore does not represent a final report.

OAK RIDGE NATIONAL LABORATORY

Oak Ridge, Tennes see 37830

operated by

UNION CARBIDE CORPORATION

for the

DEPARTMENT OF ENERGY

This report was prepared as an account of work Sponsored by the United States Government. Neither the United States nor the United States Department of Energy, nor any of their employees, nor any of their contractors, subcontractors, or their employees, makes any warranty, express or implied, or assumes any legal or usefulness of any in for the Rccuracy, completeness process disclosed, or fepresents, apparatus, product or process disclosed, or represents that its use would not
infringe privetely owned rights. 
Previous reports in this series:

ORNL/TM-5809

ORNL./TM-5936

ORNL/TM-6044

ORNL/TM-6181

ORNL/TM-6371

ORNL/TM-6410

ORNL/TM-6638 


\section{CONTENTS}

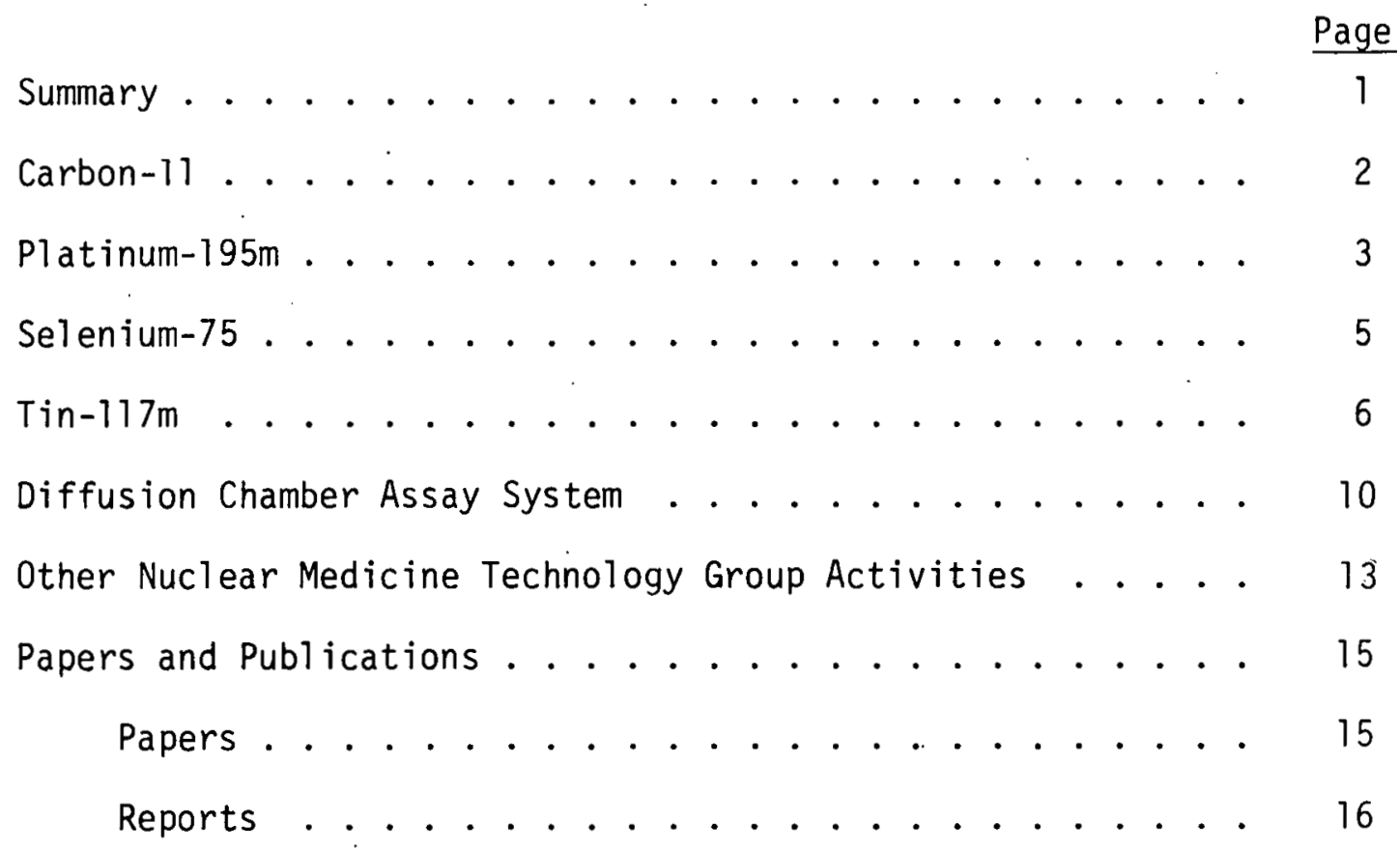


NUCLEAR MEDICINE TECHNOLOGY PROGRESS

REPORT for QUARTER ENDING SEPTEMBER 30, 1978

\section{SUMMARY}

A new area of interest in the Nuclear Medicine Technology Program is the development of a unique class of radiopharmaceuticals labeled with the ${ }^{117 m}$ Sn nuclide. The attractive properties of ${ }^{117 m}$ Sn include a 14-day physical half-life and the emission of single $\gamma$-photon with an optimal energy of $159 \mathrm{keV}$. A specialized apparatus has been designed for the conversion of metallic ${ }^{117 \mathrm{~m}_{\mathrm{Sn}} \text { to }}{ }^{117 \mathrm{~m}_{\mathrm{SnCl}}} 4$ which has been subsequently converted to a variety of useful $117 \mathrm{~m}_{\mathrm{Sn}-1 \text { abeled organotin }}$ intermediates. The availability of this unique approach will now make possible the synthesis of a wide variety of $117 \mathrm{~m}_{\mathrm{Sn}-1 \text { abeled }}$ compounds of biological interest. Such tissue-specific ${ }^{117 m}$ Sn-labeled agents may represent a new class of useful radiopharmaceuticals.

In this progress report we also describe continuing studies involving the preparation and testing of radiopharmaceuticals labeled with ${ }^{11} \mathrm{C}$, ${ }^{195 \mathrm{Ill}} \mathrm{Pt}$, and ${ }^{75} \mathrm{Se}$. Several ${ }^{11} \mathrm{C}-1$ abeled amino acids including ${ }^{11} \mathrm{C}$-DL-tryptophan, ${ }^{11} \mathrm{C}-1$-aminocyclobutanecarboxylic acid (ACBC), and ${ }^{11} \mathrm{C}-1$-aminocyclopentanecarboxyl ic acid (ACPC) were prepared, and patient studies have demonstrated ACBC to be superior to ACPC for tumor localization. Our studies with ${ }^{195 m} \mathrm{Pt}$ have recently been directed toward attempting to prepare high specific activity ${ }^{195 \mathrm{~m}_{\mathrm{Pt}}}$ by the Szilard-Chalmers process. We also report progress in the development of an in vivo diffusion chamber assay technique that is being used to investiqate the cytotoxicity of cyclophosphamide and 
cis-dichlorodiammineplatinum(II) on the growth of KB tumor cells. More recent studies with ${ }^{75} \mathrm{Se}$-labeled $\beta$-aminoethyl selenosulfate have demonstrated the significant pancreatic uptake of this agent.

\section{CARBON-11}

T. A. Butitier

Four carbon-11 production runs were made this period to prepare ${ }^{11} \mathrm{C}-\mathrm{l}$ abeled amino acids for the Medical Cooperative Program with the Oak Ridge Associated Universities (ORAU) for studies in human patients. The compounds prepared were ${ }^{11} \mathrm{C}$-DL-tryptophan, ${ }^{11} \mathrm{C}$-1-aminocyclobutanecarboxylic acid $\left({ }^{11} \mathrm{C}-\mathrm{ACBC}\right)$, and ${ }^{11} \mathrm{C}-1$-aminocyclopentanecarboxylic acid $\left({ }^{11} \mathrm{C}-A C P C\right)$. A record high yield of $417 \mathrm{mCi}$ of ${ }^{11} \mathrm{C}-\mathrm{ACBC}$ was obtained during the quarter. The $\mathrm{B}_{2} \mathrm{O}_{3}$ cyclotron target and radiochemical synthesis systems continue to have consistently good performance. Thirteen patients were examined at ORAU by positron emission tomography after administration of one or more of these agents. A sufficient number of patients have now been examined by ORAU to clearly indicate that ${ }^{11} C$-ACBC is superior to ${ }^{11} C$-ACPC for general tumor localization. Also, ${ }^{11} \mathrm{C}-\mathrm{DL}$-tryptophan appears to be superior to ${ }^{11} \mathrm{C}$-DL-valine as a pancreatic imaging agent, although, additional studies will be performed to confirm this conclusion. 
PLAT INUM-195m

J. D. Hoeschele and T. A. Butler

As part of the continuing Medical Cooperative Program to study

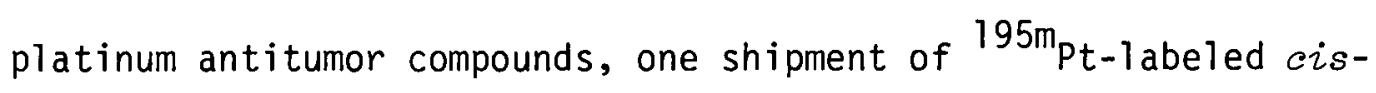
$\left[\mathrm{Pt}\left(\mathrm{NH}_{3}\right)_{2} \mathrm{Cl}_{2}\right]$ (cis-DDP) was made to the University of Southern Cali-

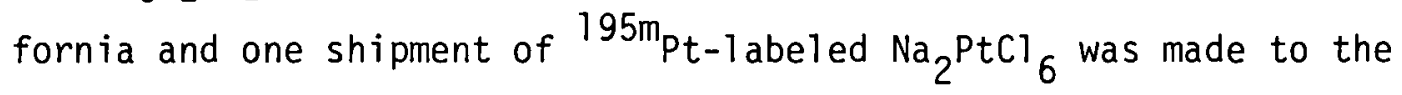
University of Kentucky Medical Center.

In cooperation with $W$. Wolf at the University of Southern California, we have initiated a short-term study to determine the feasibility of enhancing ${ }^{195 m_{\mathrm{Pt}}}$ specific activity by the SzilardChalmers process. The High Flux Isotope Reactor (HFIR) irradiation of ${ }^{194} \mathrm{Pt}$ yields ${ }^{195 \mathrm{~m}_{\mathrm{Pt}}}$ with a maximal specific activity of $\sim 1 \mathrm{mCi} / \mathrm{mg}$. as a result of the very high burn-up cross-section $\left(1.3 \times 10^{4}\right.$ barns $)$ of the ${ }^{195 m_{P t}}$ product. The availability of ${ }^{195 m}$ Pt with a specific activity greater than $5 \mathrm{mCi} / \mathrm{mg}$ would be particularly useful in

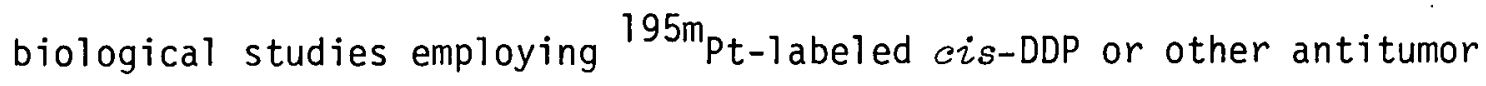
platinum compounds. Such high specific activity material would be particularly useful in studies requiring the detection of very small amounts of platinum.

In the Szilard-Chalmers process the target atoms, in this case. ${ }^{194} \mathrm{Pt}$, are irradiated in a neutron flux and converted to ${ }^{195 \mathrm{~m}_{\mathrm{Pt}}}$ by the $n \rightarrow \gamma$ nuclear reaction. The excess energy resulting from the neutron-nucleus interaction is released as a gamma photon, and to conserve momentum the nucleus receives sufficient recoil energy in most cases to rupture one or more chemical bonds. These so-called 
"hot atoms" are amenable to differential chemical recovery and thus enhancement of the specific activity of ${ }^{195 m_{P t}}$. Our initial approach will involve neutron irradiations of thermodynamically and chemically

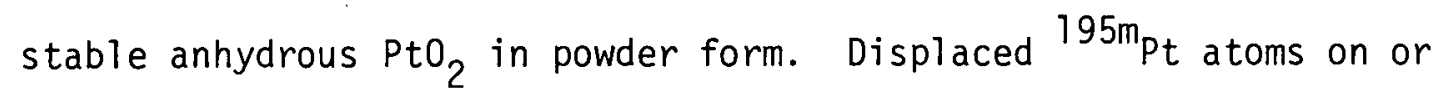
near the surface of the bulk oxide would presumably be more readily dissolved by acid leaching of the irradiated target.

Following neutron irradiation of the powdered $\mathrm{PtO}_{2}$ in the Oak Ridge Research Reactor (ORR) the target will be leached with aqua regia to remove the most reactive platinum atoms, and presumably the $195 \mathrm{~m}_{\mathrm{Pt}}$, as hexachloroplatinic acid $\left(\mathrm{H}_{2} \mathrm{PtCl}_{6}\right)$. The high molar extinction coefficient of the intense $261-\mathrm{nm}$ absorption of the $\mathrm{H}_{2} \mathrm{PtCl}_{6}$ can be easily used to determine the concentration of the leachate solutions,

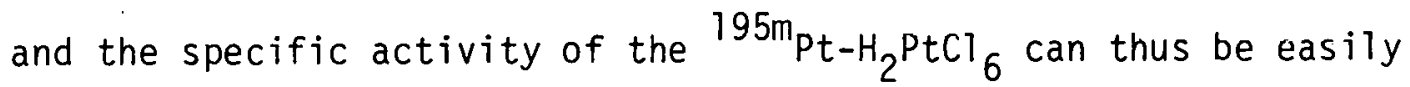
determined. The feasibility of this method for the production of

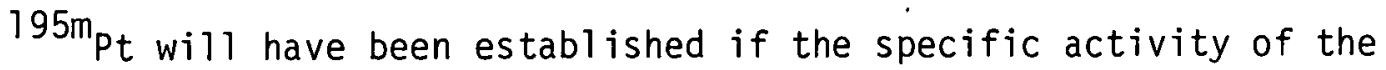
leachate is increased by a factor of 5 or more over that detected in the bulk oxide.

If the use of $\mathrm{PtO}_{2}$ is impractical for the Szilard-Chalmers process, other methods that could be considered include the neutron irradiation of platinum foil that has been electroplated with a thin copper coating. The copper may serve as a catcher for the recoiled $1.95 \mathrm{~m}_{\mathrm{pt}}$ aluills. Platinum bound to radiation stable innrganic cation exchangers or stable Pt(II) macrocyclic complexes are other potential target materials. If a feasible target material and means of removing high specific activity ${ }^{195 \mathrm{~m}_{\mathrm{Pt}}}$ is determined, then the use of highly enriched ${ }^{194} \mathrm{Pt}$ will be considered. 


\section{SELENIUM-75}

D. V. Woo, K. R. Ambrose, T. A. Butzer, and F. F. Knapp, Jr.

Our previous studies have demonstrated the significant pancreatic uptake of radioactivity in rats following intravenous administration of ${ }^{75}$ Se-B-aminoethyl selenosulfate (ORNL/TM-6410). Since commercially available ${ }^{75} \mathrm{Se}$-selenomethionine is the only agent that is routinely used for clinical pancreatic imaging, we have initiated studies to compare the biodistribution of ${ }^{75} \mathrm{Se}-\beta$-aminoethyl selenosulfate and ${ }^{75}$ Se-selenomethionine in rats. Female Fischer strain rats were intravenously administered the ${ }^{75} \mathrm{Se}-1$ abeled compounds in physiological saline solution and sacrificed 30 min later. Selected tissues were then removed and assayed for radioactivity. The resulting tissue. distribution data are shown in Table 1 and demonstrate a higher pancreatic uptake of radioactivity in animals that were administered the ${ }^{75} \mathrm{Se}-\mathrm{selenomethionine} \mathrm{compared} \mathrm{with} \mathrm{animals} \mathrm{receiving}{ }^{75} \mathrm{Se}-\beta-$ aminoethyl selenosulfate. The liver uptake, however, was considerably higher in animals that were administered the ${ }^{75} \mathrm{Se}-\mathrm{selenomethionine,} \mathrm{and}$ as a result the pancreas/liver ratios did not differ significantly for the Lwo ${ }^{75} \mathrm{Se}-\mathrm{label}$ ed compounds. These preliminary results suggest that ${ }^{75}$ Se- $\beta$-aminoethyl selenosulfate could be used as an alternative to ${ }^{75}$ Se-selenomethionine for potential imaging of the pancreas. 
Table 1. Uptake of ${ }^{75} \mathrm{Se}$ in selected rat tissues ${ }^{a}$

\begin{tabular}{lcc}
\hline & \multicolumn{2}{c}{ Compound } \\
\cline { 2 - 3 } \multicolumn{1}{c}{ Organ } & 75 Se- $\beta$-aminoethyl selenosulfate & 75 Se-selenomethionine \\
\hline Blood & $0.452 \pm 0.030$ & $0.227 \pm 0.037$ \\
Heart & $0.518 \pm 0.022$ & $0.345 \pm 0.061$ \\
Liver & $1.727 \pm 0.067$ & $2.737 \pm 0.254$ \\
Pancreas & $3.337 \pm 0.819$ & $5.340 \pm 0.813$ \\
Spleen & $0.511 \pm 0.021$ & $0.571 \pm 0.062$ \\
Pancreas/liver & 1.945 & 1.947 \\
\hline
\end{tabular}

${ }^{a}$ Average percent dose/gm of tissue or $\mathrm{ml}$ of blood \pm standard deviation for 5 animals.

TIN-117m

D. V. Woo, T. A. Butler and F. F. Knapp, Jr.

The ${ }^{117 m}$ Sn nucl ide decays with the emission of a single $\gamma$-photon in $87 \%$ abundance with an energy of $159 \mathrm{keV}$. This energy is optimal for the sodium iodide crystal detectors which are currently used in nuclear medicine instrumentation. In addition, the moderate 14-day physical half-life indicates that agents labeled with the ${ }^{117 m_{S n}}$ nuclide would have a reasonable shelf-life and that the absorbed tissue dose would be less than lhal expected for agents labeled with long-lived nuclides. Organotin chemistry is very versatile and such compounds are often quite stable. One could thus envision the prep-

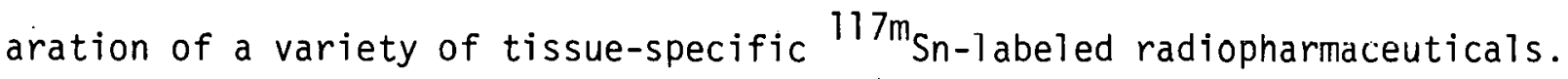
This combination of favorable radionuclidic properties, well-defined 
chemistry, and synthetic versatility has prompted us to explore the preparation of organotin compounds of potential biological interest. The synthesis of any organic ${ }^{117 m} \mathrm{Sn-1}$ abeled agent would require the

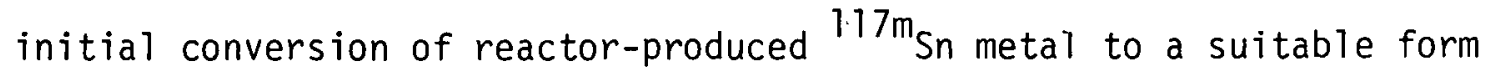
for incorporation into the compound of interest. In our estimation, tin tetrachloride $\left(\mathrm{SnCl}_{4}\right)$ 'fills the requirements of a versatile and useful intermediate for the synthesis of a wide variety of organotin compounds. We have developed a high-yield method for the conversion of tin metal to the pivotal $\mathrm{SnCl}_{4}$ intermediate. Our method involves the chlorination of metallic tin with chlorine gas with the concomitant distillation and trapping of the $\mathrm{SnCl}_{4}$ into a specialized reaction vessel as outlined in Fig. T. Using this specialized inert atmosphere, flow-through system the yields of $\mathrm{SnCl}_{4}$ have been consistently greater than $90 \%$. Reagents can be added directly to this reaction vessel for subsequent transformations which eliminates undesirable transfer and manipulation of the highly reactive $\mathrm{SnCl}_{4}$.

For the preparation of $117 \mathrm{~m}_{\mathrm{Sn}} \mathrm{l}_{\text {abeled } \mathrm{SnCl}_{4}}$ additional steps are required because of the need to accurately determine the production

ORNI - ПWG 78=19181

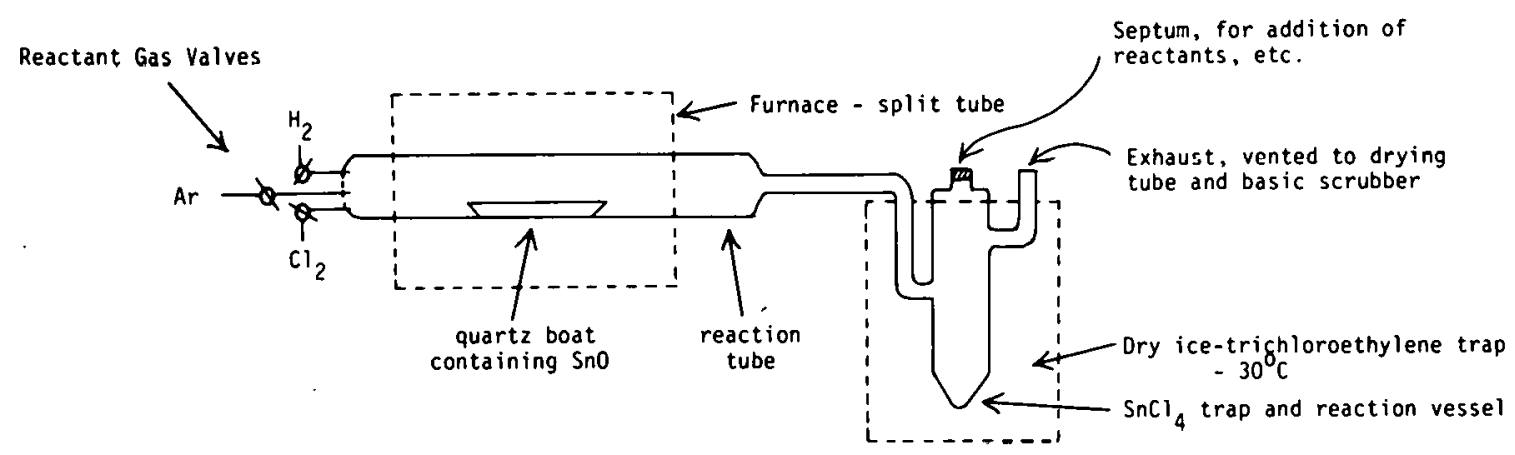

Fig. 1. Apparatus designed for the preparation of $117 m_{S n-1 a b e l e d}$ $\mathrm{SnCl}_{4}$. 
yield of $117 \mathrm{~m}_{\mathrm{Sn}}$ obtained by neutron irradiation of enriched ${ }^{116} \mathrm{Sn}$ $(n \rightarrow \gamma)$. The reactor target is dissolved in concentrated $\mathrm{HCl}$ to give a solution of hydrated tin dichloride. Aliquots of this solution are counted to determine accurately the yield and specific activity of $117 \mathrm{~m}_{\mathrm{Sn}}$. The ${ }^{117 \mathrm{~m}_{\mathrm{SnCl}}} \cdot \mathrm{H}_{2} \mathrm{O}$ is subsequently converted to the insoluble $117 \mathrm{~m}_{\mathrm{SnO}}$ by treatment with excess sodium carbonate. The ${ }^{117 \mathrm{~m}_{\mathrm{SnO}}}$ is centrifuged, washed with water, dried, and loaded into a quartz boat which is placed in the reaction tube of the apparatus illustrated in Fig. 1. The apparatus is flushed with argon gas prior to the high temperature hydrogen reduction of ${ }^{117 m_{S n O}}$ to metallic ${ }^{117 m} \mathrm{Sn}$. The system is cooled to ambient temperature and then purged again with argon gas before the introduction of a slow stream of anhydrous chlorine gas. The temperature is then slowly raised to $150^{\circ} \mathrm{C}$ and the ${ }^{117 \mathrm{~m}_{\mathrm{SnCl}}}$ distilled into the reaction vessel which is cooled in a dry-ice trichloroethylene bath. These steps are outlined below.

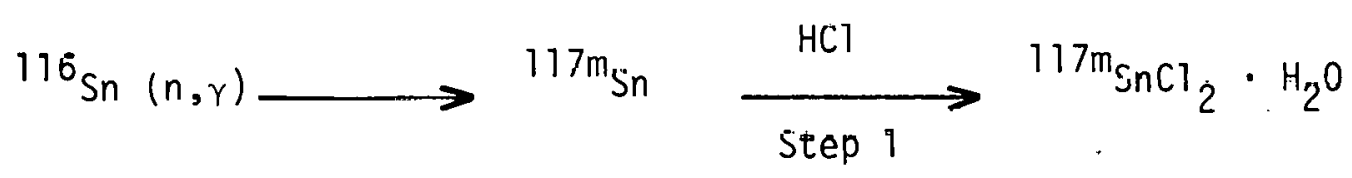

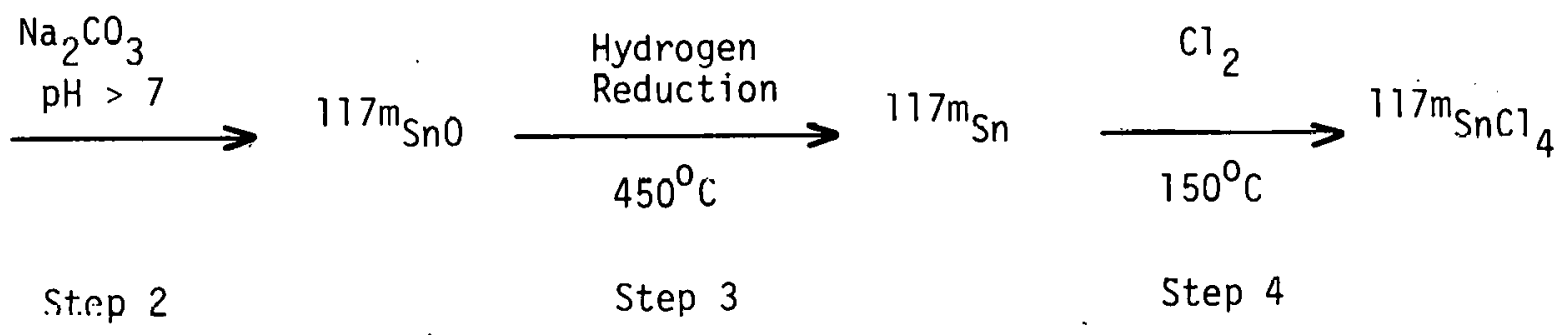

The chemical yield for the conversion of metallic tin to the Sno (steps 1 and 2) has been consistently higher than $80 \%$. Al though the yield in step (3) has not been measured directly in experiments with the radioactive tin, the overall yield in steps (3) and (4) in such 
radioactive experiments is $70-75 \%$. Experiments with stable tin gave $\mathrm{SnCl}_{4}$ with a boiling point of $114^{\circ} \mathrm{C}$ (1iterature, $114^{\circ} \mathrm{C}$ ). The $\mathrm{SnCl}_{4}$ was also reacted with a number of alkyl metal reagents as indicated in Table 2 to give a variety of useful organotin intermediates. In one experiment the $\mathrm{SnCl}_{4}$ was converted to the crystalline tetraphenyl tin by reaction with phenyl lithium. The product had a melting point of $227^{\circ} \mathrm{C}\left(1\right.$ iterature, $\left.227^{\circ} \mathrm{C}\right)$ and the infrared, ultraviolet, chromatographic, mass spectral, and nuclear magnetic resonance properties were consistent with the structure of tetraphenyl tin.

Tabie 2. Reactions of $\mathrm{SnCl}_{4}$ with alkyl metal reagents to form selected tin intermediates

\begin{tabular}{cccccc}
\hline Experiment & Substrate & Initial product & Reagent & Final product & Overall yield (\%) \\
\hline I & $\mathrm{SnO}+\mathrm{Sn}$ & $\mathrm{SnCl}_{4}$ & $\phi \mathrm{Li}$ & $\phi_{4} \mathrm{Sn}$ & 54 \\
II & $\mathrm{SnO} \rightarrow \mathrm{Sn}$ & $\mathrm{SnCl}_{4}$ & $\mathrm{CH}_{3} \mathrm{MgBr}$ & $\mathrm{Me}_{4} \mathrm{Sn}$ & 59 \\
III & $\mathrm{SnO} \rightarrow \mathrm{Sn}$ & $\mathrm{SnCl}_{4}$ & $\mathrm{Me}_{4} \mathrm{Sn}$ & $\mathrm{Me}_{3} \mathrm{SnCl}$ & 85 \\
IV & $\star \mathrm{SnO} \rightarrow \mathrm{Sn}$ & $\star \mathrm{SnCl}_{4}$ & & & 72 \\
\hline
\end{tabular}

The calculated specific activity of ${ }^{117 m_{S n}}$ produced by thermal neutron irradiation of enriched ${ }^{116} \mathrm{Sn}$ in the HFIR for 14 days at a rieutron flux of $2.5 \times 10^{15} \mathrm{n} / \mathrm{cm}^{2}-\mathrm{sec}$ is $1.0 \mathrm{mCi} / \mathrm{mg}$. Our experimentally determined specific activity of $2 \mathrm{mCi} / \mathrm{mg}$ after a 14-day irradiation of ${ }^{116} \mathrm{Sn}$ indicates that the production yield may be influenced by an epithermal neutron contribution. Specific activities of even greater than $2 \mathrm{mCi} / \mathrm{mg}$ may possibly be obtained, and experiments are being considered to determine the effect of longer irradiation periods and the effect of cadmium shielding on the production yield of $117 \mathrm{~m}_{\mathrm{Sn}}$. 
The optimization of the microscale synthesis of $117 \mathrm{~m}_{\mathrm{SnCl}_{4}}$ was necessary before the synthesis of tissue-specific $117 \mathrm{~m}_{\text {Sn-labeled }}$ compounds could be considered. Now that this crucial step has been developed we envision the synthesis of an exciting array of $117 \mathrm{~m}_{\mathrm{Sn}}$ labeled agents, including steroids, fatty acids, and amino acids. One of our major goals will be the development of the chemical strategy required to prepare these compounds.

\section{DIFFFUSION CHAMBER ASSĀY SYSTEM}

K. R. Ambrose

An in vivo diffusion chamber assay technique has been developed that represents a means of monitoring the interaction of drugs, radiopharmaceuticals, and other substances with target cells. The diffusion chambers consist of $15-\mathrm{mm}$-diam Lucite rings fitted with 0.2-micron porosity polycarbonate membranes. Target cells are loaded into the chambers through a radial hole in the Lucite ring which is then sealed with paraffin. The chambers containing the target cells are implanted in the peritoneal cavity of rats. The membranes permit the passage of nutrients from the sera that bath the chambers in the peritoneal cavity. In the same manner the cells are also exposed to drugs and agents that have been intraveneously or intraperitoneally administered to the test animals. The small pore size of the membranes, however, prevent any cells from entering or leaving the chambers. The effects of drugs administered to the test animals on the growth of cells in the test chambers can be easily monitored by counting the cells at various time intervals and comparing these results with cell counts 
from control chambers implanted in animals that received only a control saline injection. Since up to five chambers can be implanted into one animal, several measurements over a well-defined time period can be made with a limited number of animals. In a similar manner, the target cell uptake of radioactive substances injected into the test animals can be determined as well as the subcellular distribution of the test substance. The diffusion chamber technique can also be used to study the morphological changes that often occur with the target cells after treatment of the test animals with various drugs. The cells can be easily removed from the diffusion chambers for microscopic examination. We have detected such morphological changes in tumor cells in the chambers from animals treated with cis-DDP or cyclophosphamide. We are presently comparing the scanning electron micrographs of these cells with those of tumor cells obtained from chambers of control animals injected with saline.

The unique value of the diffusion chamber technique is that in vitro assays are conducted in an in vivo environment. This is quite important, for example, in the cytotoxicity studys of drugs that require in vivo activation prior to eliciting a biological response. Cyclophosphamide (Cytoxan) is a drug which requires hydroxylation by a mixed-function oxidase system prior to exhibiting its cytotoxic activity. We have used the human $K B$ nasopharyngeal tumor cell 1 ine in diffusion chamber assays to investigate the cytotoxicity of the antitumor compounds cyclophosphamide and cis-dichlorodiammineplatinum(II) (cisDDP). The intraperitoneal implantation of chambers containing $25 \times 10^{3}$ viable KB tumor cells into untreated Fischer strain rats resulted in 
an approximate 10 -fold increase in the cell population within three days. Table 3 shows the effect of intraperitoneal injections of cyclophosphamide $(75 \mathrm{mg} / \mathrm{kg})$ on the KB tumor cell proliferation. The apparent increase of inhibition of cell growth with time reflects an increase in the number of cells in the chambers from the control animals relative to a decrease in cell number in the cyclophosphamidet.reated animals.

Table 3. Effect of cyclophosphamide (CP) on growth of $K B$ tumor cells in diffusion chambers.

Average No. cells $\times 10^{3} /$ chamber

Posttreatment daya

Control group CP-treated group

Inhibitionb

\begin{tabular}{llll}
\hline 1 & 130 & 49 & $63 \%$ \\
2 & 254 & 20 & $92 \%$ \\
3 & 469 & 13 & $98 \%$ \\
\hline
\end{tabular}

$a_{\text {Animals were injected intraperitoneally with saline (control }}$ group) or cyclophosphamide one day after chamber implantation.

${ }^{2}$ Differences in cell counts between control and cyclophosphamidetreated groups are significant at $p<0.02$ as determined by the Wilcoxon test.

In similar experiments rats were injected intravenously with cis-DDP, and by the second day an $89 \%$ inhibition of KB tumor cell growth was observed in chambers from the test animals compared to the cell growth in chambers from the saline-injected control animals. In another experiment the rats were given an intraperitoneal injection of the cis-DDP, and a $92 \%$ inhibition of cell growth was observed by the 
second day. The trans-DDP isomer has been shown in numerous animal tumor model systems to be ineffective as an antitumor compound. In our diffusion chamber assay system the trans-DDP was also not cytotoxic to KB tumor cells. These combined studies show that the KB tumor cell diffusion chamber assay technique mimics the in vivo effects of cisand trans-DDP on solid tumors, and may be a sensitive general technique with which to investigate the cytotoxicity of other compounds of interest. In more recent experiments the uptake of ${ }^{195 \mathrm{~m}_{\mathrm{Pt}}-1 \text { abeled }}$ cis-DDP and ${ }^{33} \mathrm{P}-1$ abeled cyclophosphamide in KB tumor cells in the diffusion chamber assay system has been investigated.

During the next quarter the diffusion chamber assay technique will be used to further monitor the antitumor activity of cis-DDP. These studies will include different dose regimens of cis-DDP and also the combined effects of cis-DDP and cyclophosphamide treatment.

\section{OTHER NUCLEAR MEDICINE TECHNOLOGY GROUP ACTIVITIES}

Five shipments of ${ }^{43} \mathrm{~K}$ were made to the University of Mississippi for coronary disease studies including a comparison with similar images obtained using ${ }^{201} \mathrm{Tl}$ and ${ }^{81} \mathrm{Rb}$.

K. R. Ambrose, J. K. Poggenburg, and D. V. Woo attended the $25 \mathrm{th}$ : Annual Meeting of the Society of Nuclear Medicine at Anaheim, California, on July 27-30. J. D. Hoeschele attended the Euchem Conference on Coordination Chemistry and Cancer Chemotherapy in Toulouse, France, on July 24-26, and F. F. Knapp, Jr., attended the 2nd International Symposium on Radiopharmaceutical Chemistry held at Oxford University on July 2-7. 
F. F. Knapp, Jr., visited the Biochemistry Department, Rice University at Houston, lexas, on September 6-8 where he presented an invited seminar describing the recent work of the Nuclear Medicine Technology Group and conferred with faculty members concerning potential areas of collaborative research. On September $11-12$ he visited the Chemistry Department of Texas A \& M University at College Station, Texas, to discuss establishing a collaborative research program with Dr. K. J. Irgolic for the synthesis of organotin and organotellurium compounds of biologicai interest. D. V. Woo attended the 2nd International Congress of the World Federation of Nuclear Medicine and Biology in Washington, D. C., on September 17-21.

K. R. Ambrose attended a two-week course on Radioimmunoassay Systems at the Philadelphia College of Pharmacy from July 31 to August 11 .

On September 16th J. K. Poggenburg joined the new Medical Products Division of Union Carbide Corporation as Manager of Radiopharmaceutical Research and Development.

Visitors for this period included Mr. Mohammed Zin Bin Che Awang and Mr. Badruddin Bin Chepa who joined the Nuclear Medicine Technology Group for three months to investigate the potentia1 production of high specific activity ${ }^{195 m_{P t}}$ by the Szilard-Chalmers process. This work was initiated as part of a collaborative effort with Dr. Walter Wolf at the University of Southern California to study the biological properties of platinum antitumor compounds. 


\section{PAPERS AND PUBLICATIONS}

\section{Papers}

F. F. Knapp, Jr., K. R. Ambrose, and A. P. Callahan, "The Effect of Nuclear and Sidechain Modifications on the Adrenal Uptake of Telluro Steroids Labeled in the Sidechain with Te-123m," 2nd International Symposium on Radiopharmaceutical Chemistry, Oxford University, July 2-7, 1978.

F. F. Knapp, Jr., K. R. Ambrose, and A. P. Callahan, "Synthesis, Characterization and Properties of Telluro Amino Acids: A New Class of Potential Pancreatic Imaging Agents, " 2nd International Symposium on Radiopharmaceutical Chemistry, Oxford University, July 2-7, 1978.

J. D. Hoeschele, N. P. Johnson, and R. O. Rahn, "Comparative Binding/ Distribution Studies of Pt-195m-Labeled Cis- and Trans-Dichlorodiammineplatinum(II) (DDP) in the Rat with Emphasis on Localization in DNA," Euchem Conference on Coordination Chemistry and Cancer Chemotherapy, Toulouse, France, Ju1y 24-26, 1978.

D. V. Woo, A. P. Callahan, K. R. Ambrose, T. A. Butler, and F. F. Knapp, Jr., "The Synthesis of Se-75-l aheled B-Aminoethyl Selenosulfate: A New Potential Agent for Imaging of the Heart," 2nd International Congress of the World Federation of Nuclear Medicine and Biology, Washington, D. C., September 17-21, 1978. 


\section{Reports}

F. F. Knapp, Jr., Nuclear Medicine Technology Progress Report for Quarter Ending June 30, 1978, ORNL/TM-6638. 
ORNL/TM-6639

INTERNAL DISTRIBUTION

$\begin{aligned} & \text { 1. } \text { K. R. Ambrose } \\ & \text { 2. S. I. Auerbach } \\ & \text { 3. J. A. Auxier } \\ & \text { 4. J. M. Becker (Consultant) } \\ & \text { 5. T. A. Butler } \\ & \text { 6. J. A. Cox } \\ & \text { 7. } \text { J. M. Dougherty } \\ & \text { 8. R. B. Gammage } \\ & \text { 9. A. S. Garrett, Jr. } \\ & \text { 10. W. R. Garrett } \\ & \text { 11. } \\ & \text { J. D. Hoeschele } \\ & \text { 18-17. S. S. V. Kaye } \\ & \text { 23. } \text { E. F. Knapp, Jr. } \\ & \text { 24. } \text { B. F. Maskewitz } \\ & \text { 25. C. H. Nowlin } \\ & \text { 26. C. L. Ottinger }\end{aligned}$

27. D. C. Parzyck

28. H. Postma

29. M. E. Ramsey

30. C. R. Richmond

31. A. F. Rupp (Consultant)

32. C. D. Scott

33. W. D. Shults

34. M. R. Skidmore

35. J. B. Storer

36. P. J. Walsh

37. D. V. Woo

38. H. A. Wright

39-40. Central Research Library

41. Document Reference Section

42-43. Laboratory Records Department

44. Laboratory Records, ORNL RC

45. ORNL Patent Section

\section{EXTERNAL DISTRIBUTION}

46. S. James Adelstein, M.D., Shields Warren Radiation Lab., Boston, MA 02115

47. H. L. Atkins, M.D., BNL, Upton, N.Y 11.973

48. A. B. Brill, MD, Vanderbilt Univ. Hospital, Nashville, TN 37232

49. T. F. Budinger, M.D., Donner Lab., LBL, Berkeley, CA 94720

50. Philip A. DeSimone, M.D., V.A. Hospital, Lexington, KY 40507

51. Paul Harper, M.D., Frankl in McLean Memorial Research Institute, Chicago, IL 60637

52. R. L. Hayes, ORAU, Oak Ridge, TN 37830

53. John Holl ifield, M.D., Vanderbilt Univ. Hospital, Nashville, TN 37232

54. K. J. Irgolic, Chemistry Dept., Texas A\&M Univ., College Station, TX 77840

55. David E. Kuhl, M.D., UCLA, Lab. of Nuclear Medicine, Los Angeles, CA 90024

56. John S. Laughlin, Sloan-Kettering Inst. for Cancer Research, New York, NY 10021

57. A. Lengendre, M.D., UT-School of Veterinary Medicine, Knoxville, TN 37920

58. C. C. Lushbaugh, ORAU, Oak Ridge, TN 37830

59. J. N. Maddox, DOE-OHER, Washington, DC 20545

60. Office of Assistant Manager, Energy Research and Development, DOE-ORO, Oak Ridge, TN 37830

61. H. A. O'Brien, LASL, Los Alamos, NM 87545

62. J. K. Poggenburg, Medical Products Division, UCC, Tuxedo, NY 10987

63. P. Richards, BNL, Upton, NY 11973 
64. A. Solomon, M.D., UT MRCH, Knoxville, TN 37920

65-91. Technical Information Center, DOE, Oak Ridge, TN 37830

92. John Venditti, National Cancer Institute, Silver Springs, MD 20910

93. H. E. Walburg, CARL, Oak Ridge, TN 37830

94. W. H. Weyzen, M.D., DOE-OHER, Washington, DC 20545

95. A. P. Wolf, BNL, Upton, NY 11973

96. Walter Wolf, University of Southern California, Los Angeles, CA 90033

97. R. W. Wood, Jr., OHER, Washington, DC 20545 